\title{
2. EOCENE PALEOGEOGRAPHY OF THE SOUTHEASTERN CARIBBEAN: RELATIONS BETWEEN SEDIMENTATION ON THE ATLANTIC ABYSSAL PLAIN AT SITE 672 AND EVOLUTION OF THE SOUTH AMERICA MARGIN1
}

\author{
Christian Beck, ${ }^{2}$ Yujiro Ogawa, ${ }^{3}$ and James Dolan ${ }^{4,5}$
}

\begin{abstract}
A well-recovered Tertiary sedimentary succession was drilled on the Atlantic abyssal plain during ODP Leg 110. The succession includes a conspicuous turbiditic-contouritic series deposited during the middle to late Eocene and the Oligocene. The exotic silty-sandy content of the middle-upper Eocene sequence is compared with the coeval Caratas Fm. of northern Venezuela. The decrease and disappearance of this coarse material at the Eocene/Oligocene boundary is related to the eastward displacement of the Caribbean Plate and the associated removal of previously available sediment sources.
\end{abstract}

\section{INTRODUCTION}

During DSDP Leg 4, the portion of Atlantic abyssal plain extending east of the Barbados Ridge and north of the Guyana shelf (Fig. 1), was drilled twice (Sites 26 and 27). The occurrence of thin terrigenous silty-sandy layers, considered as turbidites, led the Shipboard Scientific Party (1970) to discuss the origin of these coarse components and to propose that they were transported from the Amazon cone (Site 26) and locally mixed with volcanic arc-derived components (Site 27). More recent investigations on the Island of Barbados (Speed, 1981; Speed and Larue, 1982; Pudsey and Reading, 1982) and offshroe (Wright, 1984; Pudsey, 1984; Latouche and Maillet, 1984) dealt with the contribution of the Guyana margin (and especially the Orinoco and Amazon deltas) to the terrigenous sediments of the Atlantic abyssal plain, and, by the means of accretion, to the building of the Barbados Ridge complex. The detailed distribution of surficial sediments studied by Wright (in Speed, Westbrook et al., 1984) demonstrates clearly the present contribution from the Guyana shelf and the Orinoco and Amazon cones, and the role of bottom currents flowing northwestward along the Guyana margin. A similar interpretation was proposed by Latouche and Maillet (1984) for Paleogene and Neogene sedimentation (DSDP Leg 78A, Site 543; Shipboard Scientific Party, 1984), on the basis of clay mineral supply. ODP Leg 110, dedicated to the study of the Barbados Ridge accretion, recovered a complete Eocene to Pleistocene section at Site 672 , about $20 \mathrm{~km}$ south of Site 543. The middle-upper Eocene and Oligocene sediments are strikingly different from those of Site 543. The former consist of hemipelagic claystone with numerous interbedded fine-grained calcareous turbidites (corresponding to the model by Stow and Piper, 1984). Furthermore, the Oligocene section contains scattered quartzose silt laminae, and the middle-upper Eocene contains medium to very fine sand layers, up to $40 \mathrm{~cm}$ thick (Ship-

\footnotetext{
${ }^{1}$ Moore, J. C., Mascle, A., et al., 1990. Proc. ODP, Sci. Results, 110. College Station, TX (Ocean Drilling Program).

2 Sciences de la Terre, C.N.R.S. U.R.A. 694, Université de Savoie, B. P. 1104 Chambéry Cedex, France.

${ }^{3}$ Department of Geology, Faculty of Sciences, Kyushu University, Hakozaki, Fukuoka, Japan.

${ }^{4}$ Earth Sciences Board, University of California, Santa Cruz, CA 95065 , U.S.A.

5 Now at U.S. Geological Survey, Pacific Marine Geology, MS 999, 345 Middle Field Rd., Menlo Park, CA 94025.
}

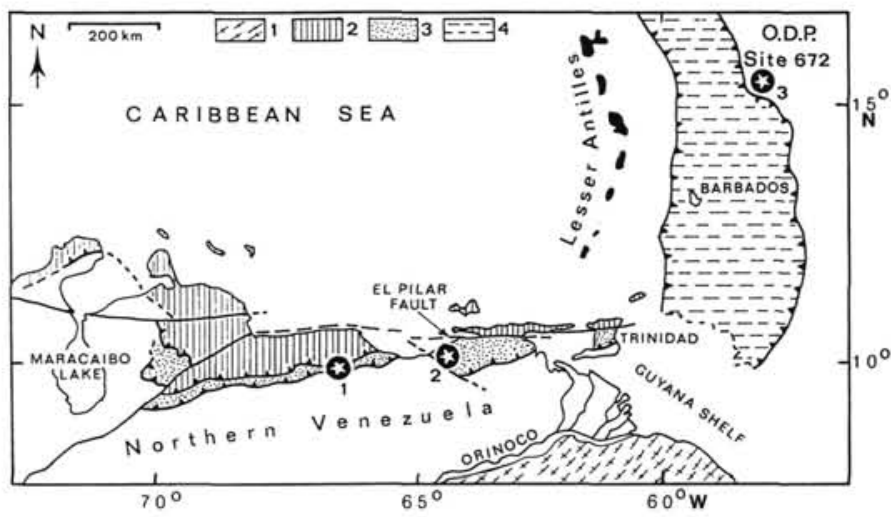

Figure 1. Generalized map of the southeastern Caribbean showing the areas compared in this study. Legend: 1, Guyana Shield; 2, Coast Range; 3, Tertiary foreland belt; 4 , Barbados accretionary complex.

board Scientific Party, 1988; Dolan et al., this volume). The land-based investigation in northern Venezuela conducted by the senior author led us to discuss the sources of the coarse terrigenous components at Site 672, taking into account the geodynamic evolution of the southeastern Caribbean and especially the eastward motion of the Caribbean Plate along northern South America (see Molnar and Sykes, 1969; Bell, 1972; Stéphan, 1982). Thus, if the Guyana margin southeast of Trinidad (Fig. 1) is a source for Neogene-Holocene sedimentation, the northern Venezuela margin might have been important for Eocene sedimentation.

In this paper we present the lithostratigraphy of Site 672, then focus on the middle Eocene-Oligocene portion and compare it with the coeval sediments of northern Venezuela foreland belt (areas 1 and 2 on Fig. 1) and propose relations between Site 672 Paleogene sedimentation and structural evolution of northern South America are proposed.

\section{CENOZOIC SEDIMENTATION ON THE ATLANTIC ABYSSAL PLAIN SITE 672 (Area 3, Fig. 1)}

The detailed observations made during the cruise (Shipboard Scientific Party, 1988) were subsequently augmented by the analysis of 125 samples regularly spaced along the $492 \mathrm{~m}$ of cored sediments. The clay mineral assemblages of these samples are presented and discussed by Capet et al. (this volume); we focus 
on bulk composition of these sediments and on their silty-sandy components.

\section{General Description}

For the different columns of Figures $2 \mathrm{~A}$ and 3 we used the biostratigraphic boundaries and the lithologic subdivisions (units) proposed in Shipboard Scientific Party (1988). Calcareous nannoplankton, radiolarians, and foraminifers-studied by Clark, Sakai, and Andreieff (Shipboard Scientific Party, 1988)-provided a detailed stratigraphic control. For all samples from Site 672 , texture of total sediment, composition, and texture and composition of the terrigenous fraction were analyzed to discuss their "allochthonous" origin (see also Dolan et al., this volume).

Each sample was divided into three fractions: sand, coarse silt, and medium silt to clay, for microscopic counting on smear slides and impregnated thin sections; biogenic calcareous content (foraminifers and nannoplankton) is mainly based on shipboard carbonate-bomb data. The results-for which we assume a $5 \%$ accuracy-are plotted on two triangular diagrams (Fig. 4) corresponding to values from middle and right columns of Figure 3 (one point on each triangle per sample). For these diagrams the observed authigenic carbonates were neglected and

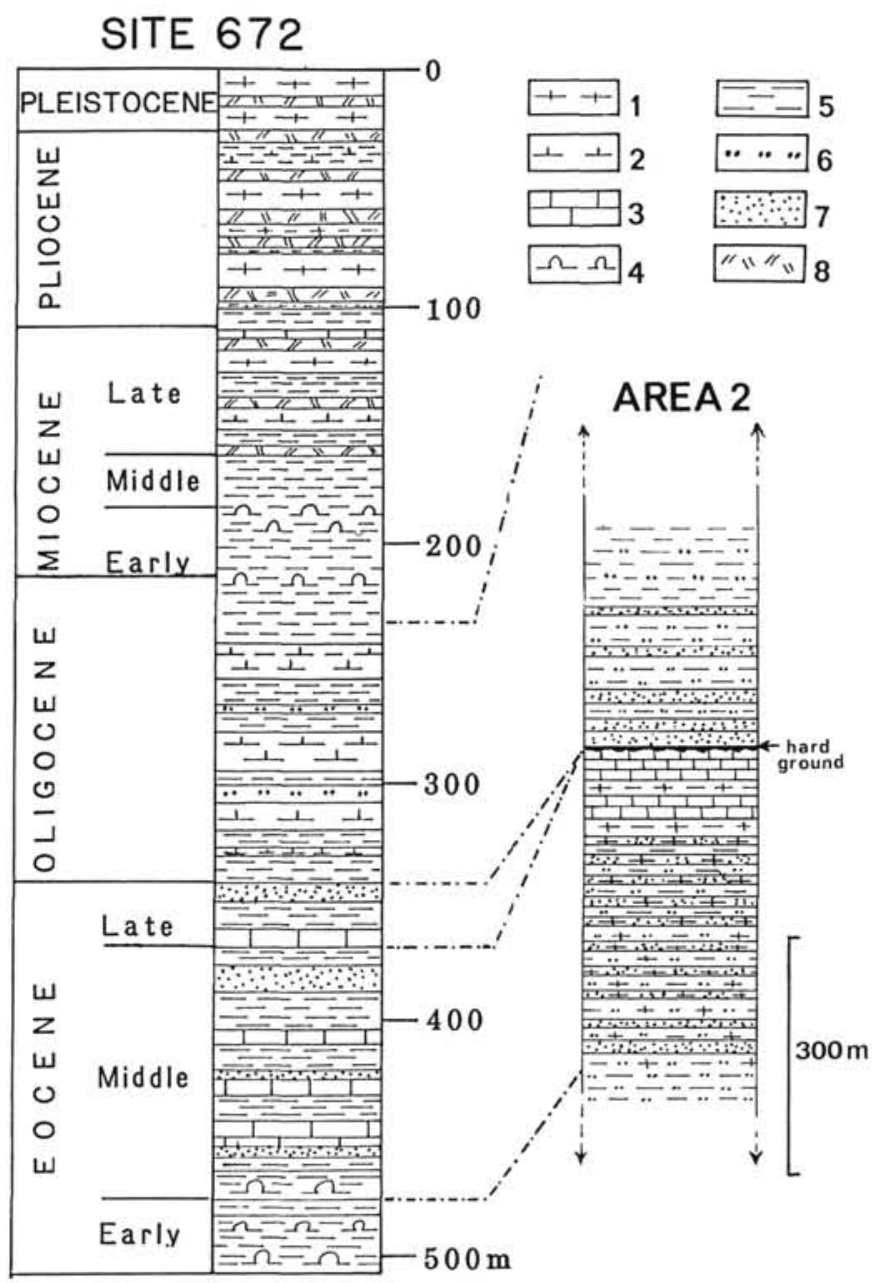

Figure 2. Simplified stratigraphy of areas 2 and 3. Legend: 1, calcareous ooze and clay (foraminifer and nannofossil); 2 , calcareous clay (nannofossil); 3 , chalk, limestone; 4 , siliceous clay to claystone; 5 , clay to claystone, mud to mudstone; 6 , silt; 7 , sand to sandstone; 8 , volcanic ash. the whole clay mineral content was considered as terrigenousalthough part of it is due to subaqueous alteration of volcanic ash (see Capet et al., this volume; Schoonmaker tribble, this volume).

\section{Topmost Miocene-lower Pleistocene (Unit 1)}

This interval is composed of hemipelagic calcareous mud or clay; the silt- and sand-size fractions mainly correspond to calcareous tests (see middle column, Fig. 3 ) and locally to terrigenous elements (peaks on right column). The latter are essentially volcanic air-fall products (vitric or crystalline). The Pleistocene section contains a minor biogenic siliceous component. Figure 4A illustrates the continuous variations in calcareous content and the clayey texture of the terrigenous fraction.

\section{Miocene Interval (Unit 2, Including a Barren Portion)}

This interval lacks biogenic calcareous elements and is mainly composed of clay and claystone with local volcanic ash (see peaks on right column, Fig. 3). The lower Miocene (Subunit 2B of Mascle, Moore, et al., 1988) is a siliceous-rich interval (Fig. 4B) and corresponds to the "décollement" horizon within the frontal part of the accretionary complex. Radiolarians, which are the major siliceous component, are highly fragmented and occur within the silt-size fraction. The terrigenous silt-size fraction corresponds to volcanic ash. We note that within this siliceous interval, and just above it, most of our samples contain a significant amount of authigenic carbonate (rhodochrosite and dolomite). Their occurrence may be related to the high pore-water circulation that was demonstrated by geochemical studies (Moore, Mascle, et al., 1987; Blanc et al., 1988; Gieskes et al., in press) and by the existence of fluid-escape structures ("veins") within lower Miocene cores. Figure 4B illustrates the general characteristics of the whole interval.

\section{The Oligocene Interval (Unit 3)}

This interval shows a highly variable silt content (left column, Fig. 3), which corresponds to a variable biogenic calcareous content (foraminifer fragments and nannoplankton). Figure 4C illustrates the distinct calcareous-rich and calcite-free samples, although our samples were regularly spaced without choice of calcareous or non-calcareous strata that were easily distinguishable on split cores. The shipboard observations of sedimentary structures led the Shipboard Scientific Party (1988) to interpret the Oligocene interval as the result of interbedding of calcareous fine-grained turbidites within slow hemipelagic noncalcareous sedimentation. Locally (see middle column, Fig. 3), a small amount of biogenic siliceous fragments occur in these turbidites. Very fine sand and coarse-grained silt were observed in the terrigenous fraction of several samples (see short peaks on right column, Fig. 3). These coarser intervals correspond to thin (1 to $3 \mathrm{~mm}$ ) quartzose laminae that may be related to bottom contour current activity.

\section{Middle-upper Eocene Interval (Unit 4)}

The lithologic contrast observed in Unit 3 is also present but not as distinct (see middle column, Fig. 3, and Fig. 4D); this is due to the occurrence of both calcareous fine-grained turbidites and moderately calcareous sandy contourites vs. turbidites (Shipboard Scientific Party, 1988). The observation of split cores and further analysis of the stratification show that the occurrence of the two types of layers are generally independent. Furthermore, in some samples, the terrigenous fraction is highly sandy. We observed a significant amount of authigenic carbonate in the middle-upper Eocene sediments, especially in the sandy layers, where pore-water chemistry results suggest that high fluid circulation rates existed (Blanc et al., 1988; Gieskes et al., in press). 


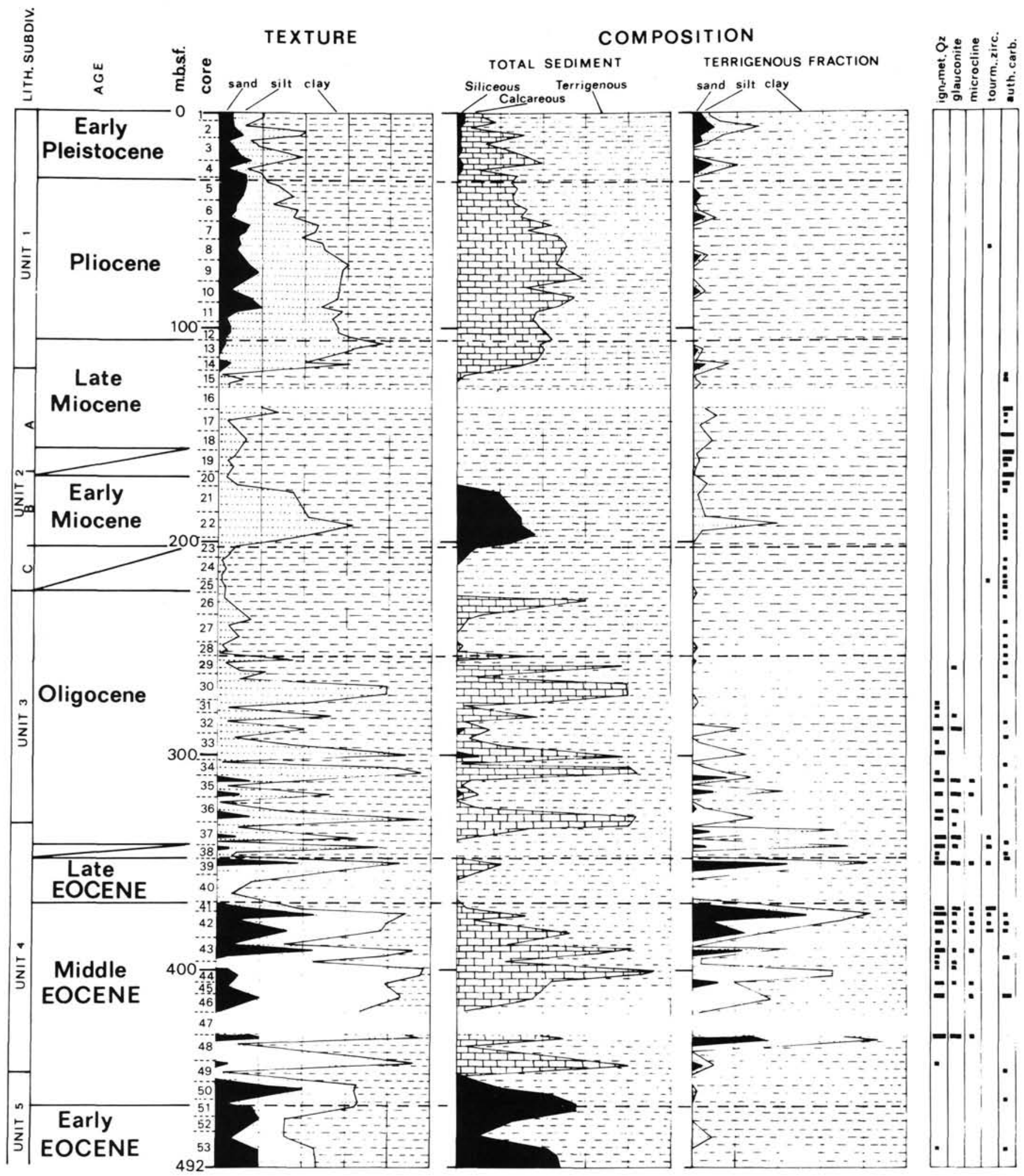

Figure 3. Variations of texture and composition of Tertiary sediments from the Atlantic abyssal plain at ODP Site 672. (Left column: texture of total sediment; middle column: composition of total sediment; right column: texture of terrigenous fraction.) 

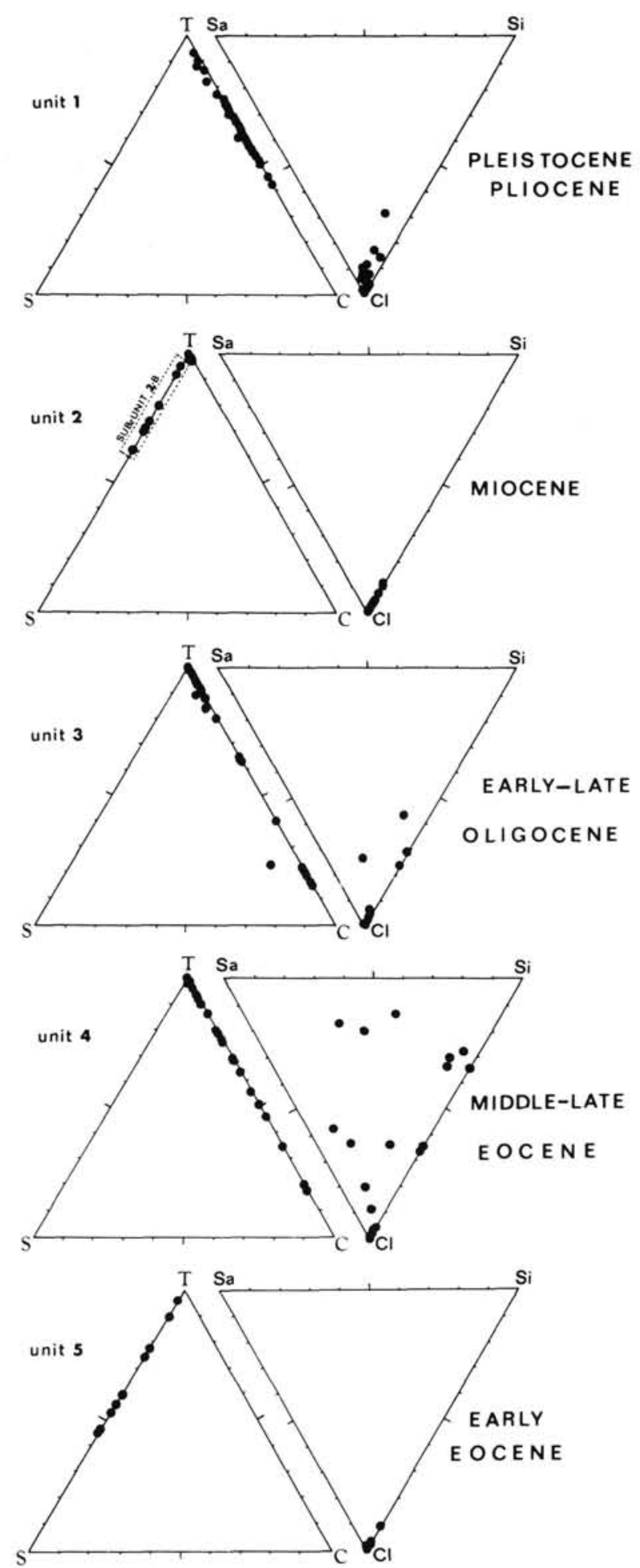

Figure 4. Diagrammatic representation of lithostratigraphic units of ODP Site 672. Legend: T-C-S diagram refers to the bulk composition of sediment; T, terrigenous; C, biogenic calcareous; S; biogenic siliceous; Sa$\mathrm{Si}-\mathrm{Cl}$ diagram refers to the texture of terrigenous fraction; $\mathrm{Sa}$, sand; $\mathrm{Si}$, silt; $\mathrm{Cl}$, clay; ( $\%$ scale refers to volumetric ratios).

\section{Lower Eocene Interval (Unit 5)}

This unit is represented by siliceous hemipelagic sedimentation, without terrigenous silt or sand (see middle and right columns, Fig.3; and Fig. 4E).

\section{Turbiditic-contouritic Material of the Middle Eocene to Oligocene Interval}

Within the Oligocene section, layers formed from lateral sources of sediment input represent about 30 to $40 \%$ of the total thickness. These layers form about $60 \%$ of some middle Eocene cores. "Exotic" silt- and sand-size particles were found in different settings:

- Layers, up to $40 \mathrm{~cm}$ thick, of calcareous fine to medium sand, cross-laminated (middle-late Eocene);

- Thin (1 to $3 \mathrm{~mm}$ ) very fine sand to coarse silt laminae (Oligocene);

- In minor amounts, mixed within the base of fine-grained calcareous turbidites (Eocene and Oligocene); the latter are assigned to local gravity slope process related to oceanic floor relief, such as the nearby Tiburon Rise (see Dolan et al., this volume).

Among the exotic particles (several types are indicated on the right side of Figure 3) we note:

-Igneo-metamorphic quartz; polycrystalline grains with "sutured"-type boundaries;

-Glauconite: well-rounded, sometimes slightly altered, very fine sand-size grains;

-Feldspars: fresh microcline (locally reaching $1 \%$ of the sand fraction), and twinned, slightly saussuritized, plagioclases;

-White mica, epidote, glaucophane, barroisite, and unidentified chloritized minerals;

-Accessory minerals: Tourmaline and zircon.

Transported biogenic coarse particles are abundant either in calcareous turbidites or in sand layers: planktonic foraminifers (complete, sometimes recrystallized, biserial tests; Globigerinids fragments), rare fragments of small benthic foraminifers, opaque-epigenized spicules, and radiolarian fragments. Plant fragments and fish debris are also common.

Remarks:

1. Most of the mentioned allochthonous components were described in DSDP Site 27 younger sediments (Shipboard Scientific Party, 1970);

2. Rock-Eval organic carbon analyses carried out during Leg 110 pointed to a mainly terrestrial origin for the upper EoceneOligocene interval (Shipboard Scientific Party, 1988);

3 . Some mineral grains will be analyzed with microprobe in further investigations.

\section{Short Comparison of Middle-upper Eocene and Oligocene}

Looking at the grain size of the terrigenous fraction, the middle-upper Eocene sediments appear mainly sandy, with a higher total amount of coarse component (see right column, Fig. 3; and Fig. 4D), while the Oligocene is essentially silty and more clayey. In both, the coarse terrigenous material is wellsorted (a sandy group around $0.200 \mathrm{~mm}$, a silty-sandy group between 0.040 and $0.080 \mathrm{~mm}$ ); this grain-size character may indicate a mostly contouritic origin, although silt-size grains of the same nature are reworked into distinct turbidites. A clear correlation exists between sandy-silty texture, high calcareous content (reworked foraminifers), sand-size terrigenous particles, and occurrence of igneo-metamorphic quartz, and glauconite, especially in middle-upper Eocene interval (see peaks on Fig. 3). The same correlations appear in the lower part of the Oligocene, but the terrigenous fraction becomes only silty; calcareous peaks stay high and correspond to nannoplankton (see also Dolan et 
al., this volume). All these observations and correlations reinforce the interpretation of the silty-sandy-terrigenous as well as calcareous-fraction as material transported and redeposited below CCD.

\section{OUTLINE OF THE EOCENE-OLIGOCENE SEDIMENTATION AND STRUCTURAL EVOLUTION OF THE NORTHERN VENEZUELA FORELAND BELT}

Northern South America is bounded by a polyphasic complex orogene of Mesozoic-Cenozoic age-the Caribbean Mountain System or Caribbean Chain (Bellizzia, 1972; Bell, 1972; Stéphan et al, 1980)-which extends through northern Venezuela, Trinidad, and Tobago (Fig. 1). The Tertiary foreland basin of the Caribbean Chain remained undefomed or little deformed in the Maracaibo Lake area, while, east of it, Tertiary sediments underwent tectonic shortening, mostly during the middle-upper Eocene (east of Maracaibo Lake to area 1) and the middle Miocene (area 2 and east of it). These deformation episodes, sometimes preceded by olistolitic-olistostromic phenomena, are considered by Stéphan $(1982,1985)$ as the southernmost consequence of the eastward movement of the Caribbean Plate, whose southern margin is represented by the metamorphic Coast Range (Fig. 1). This "transpression" tectonics (Stéphan, 1982) involved huge east-west dextral strike-slip faults-like the El Pilar System (Vierbuchen, 1978)-and thrusting farther southeastward.

During the Paleocene to middle Eocene, the northern part of the foreland basin-in area 1-received a thick terrigenous turbiditic fill (the Guárico flysch; see Peirson et al, 1966; Bell, 1968; Beck, 1986) while the southern portion acted as an unstable platform and its upper continental slope (Galea-Alvarez, 1985; Rossi, 1985; Beck, 1986) with both calcareous and terrigenous sediments. In Trinidad-the easternmost portion-turbidites and olistolithic phenomena were reported in younger sediments (Kügler and Saunders, 1967), while the Eocene-Oligocene interval corresponds to a clayey and calcareous quiet platform sedimentation (Barr and Saunders, 1968; Saunders, 1974). The Eocene-Oligocene lithology, facies, and main changes in sedimentation of areas 1 and 2 show several important similarities with the Eocene-Oligocene of area 3. Thus, we choose to compare Site 672 with northeastern Venezuela.

\section{Eocene Lithostratigraphy of Two Reference Sections}

The successions presented on Figure 5-and summarized on Figure 2-were studied in southern, slightly deformed, outcrops of the foreland belt; section 1 is from Beck (1986) and section 2 is from Gonzalez de Juana et al. (1980), modified according to Rossi (1985), Galea-Alvarez (1985), and Beck (unpublished data). Section 1 is close to an area that underwent Eocene compressive deformation (note olistoliths occurrence; OI on Fig. 5), while section 2 belongs to a large area-the eastern Venezuela Basin (Hedberg, 1950)-where no Eoene deformation was reported.

In both areas, the succession can be summarized as follows (Figs. 2-B and 5):

-fine terrigenous sedimentation during the Paleocene and basal Eocene (shales, siltstones, claystones);

- fine to coarse terrigenous sedimentation during the early Eocene (silty shales locally calcareous, quartzose sandstones);

-mixed biogenic calcareous and fine to coarse terrigenous sedimentation during the middle Eocene (calcareous silty-sandy shales to coarse calcareous sandstones); this corresponds to distal platform or upper slope facies with a large conspicuous amount of glauconite (sometimes reaching $50 \%$ of the whole rock) in foraminifer quartzose sandstones as well as in calcareous shales (with nannoplankton). The middle Eocene ends with

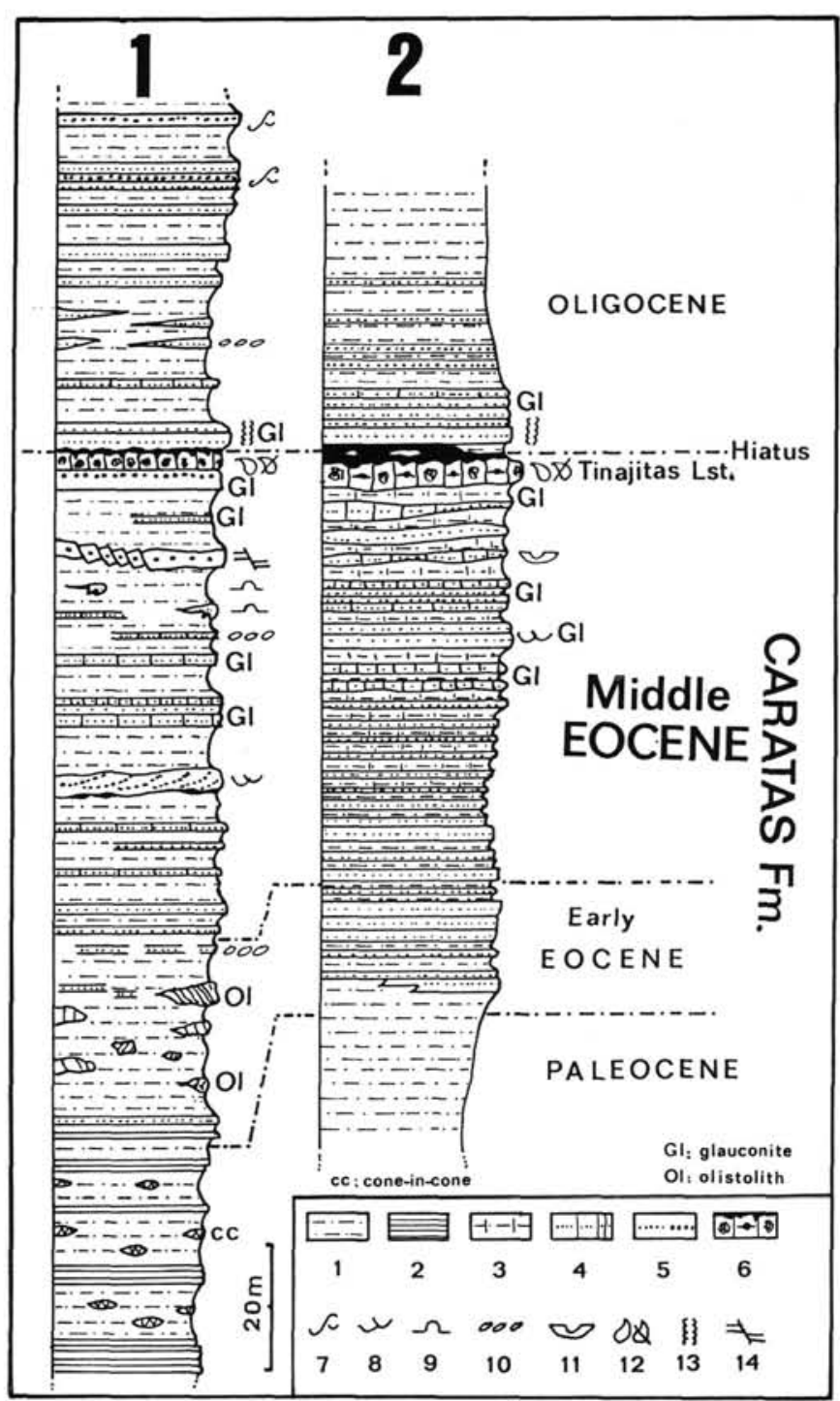

Figure 5. Lithostratigraphic synthesis of the Paleogene in northeastern Venezuela foreland belt (areas 1 and 2 on Fig. 1). (Data from Gonzalez de Juana et al., 1980; Beck, 1986; Galea-Alvarez, 1985; Rossi, 1985). Legend: 1 , shales; 2 , siltstone; 3 , calcareous shales; 4 , calcareous sandstone and sandy limestone; 5 , fine to coarse sandstone; 6 , algal-foraminifer limestone; 7 , flaser bedding; 8 , cross bedding; 9 , slump; 10 , lenticular stratification; 11 , channelized facies; 12 , complete or fragmented shells; 13, Ophiomorpha; 14, syn-sedimentary fault; GI, glauconite; OI, olistolith.

a widespread limestone episode (algae and large benthic foraminifers; see Galea-Alvarez, 1985);

- the upper Eocene is missing and represented by a hard ground;

-the Oligocene represents the beginning of a huge molassic section, very coarse at the base and grading into more shaly sequences; these series have paralic to coastal facies associated to strong subsidence.

Comparing the sedimentary succession of areas 1 and 2 (Fig. 5), we note the same major lithological changes; the middle-upper Eocene being calcareous and glauconite-rich. The major difference concerns sedimentary process: In area 1, the Eocene sequence shows evidences for gravity phenomena (slumps, syn- 
sedimentary faults) that we explain by deposition on upper continental slope (see also Galea-Alvarez, 1985). In both sedimentary successions, the glauconite grains (often visible inside complete foraminifer tests) do not show evidences of important reworking; the quartz grains correspond to medium to coarse sand; and we did not observe clear evidences for turbiditic emplacement. A major change in Paleogene sedimentation occurred by the end of the Eocene. Prior to that time an open-sea sedimentation was in place, with northern deeper and more hemipelagic facies. During the late Eocene sedimentation was separated from northern marine influences and became related to eastern to southeastern marine influence (Galea-Alvarez, 1985; Rossi, 1985; Beck, 1986). We tie this major change to the tectonic evolution as outlined below.

\section{Chronology and Geometry of Tertiary Deformation of Northern Venezuela Foreland Belt (Figs. 6 and 7)}

The results of structural analysis of the Paleogene-Neogene series of area 1 (Beck, 1986) is summarized in Figure 6; this chronology is available for area 1 (Fig. 7). A similar succession was observed elsewhere along northern Venezuela (Stéphan, 1982; Rossi, 1985, Chevalier, 1987) but the main events appear younger toward the east; in area 1, no Eocene compressive deformation has been reported. In southeastern Trinidad, Pliocene to Holocene deformation and mud-diapirism are reported (Higgins and Saunders, 1974; Rossi, 1985).

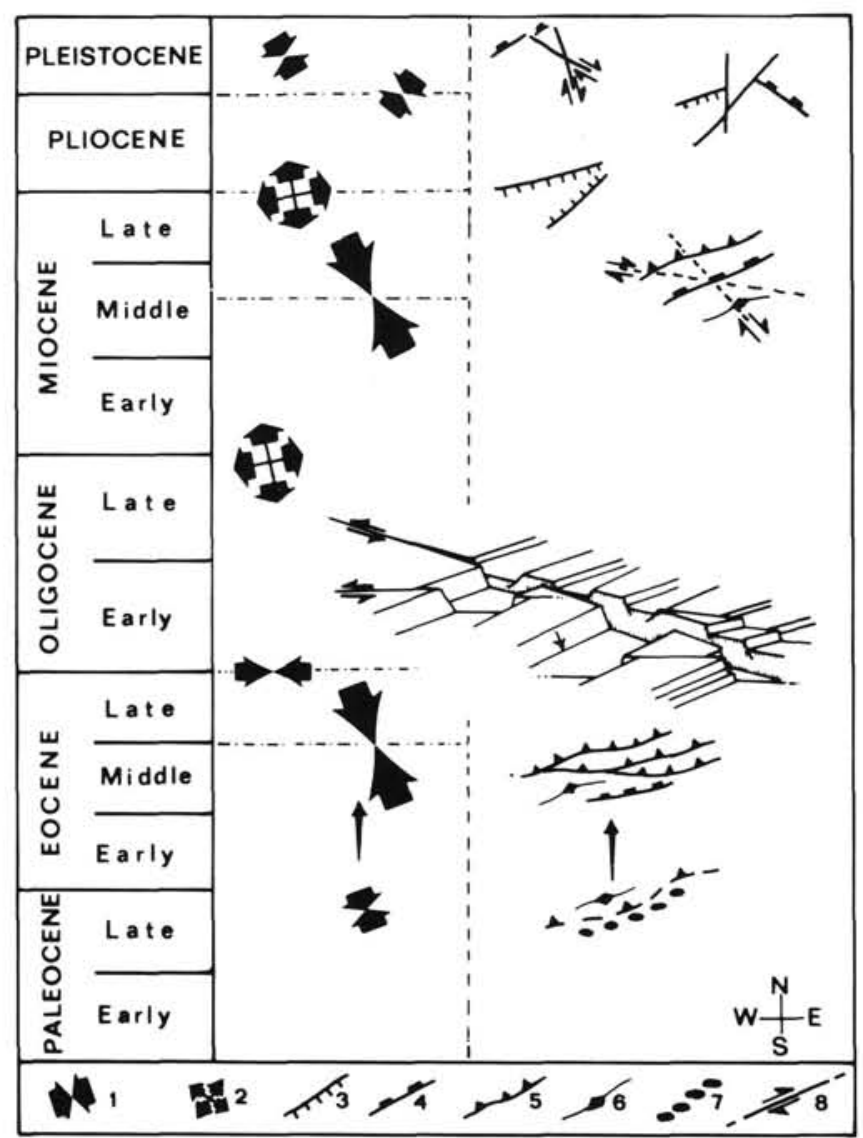

Figure 6. Diagrammatic outline of Tertiary structural evolution of the northeastern Venezuela foreland belt. (Modified from Beck, 1986). Legend: 1 , compression; 2 , multidirectional extension; 3 , normal faulting; 4 , reverse faulting; 5 , thrusting; 6 , folding axis; 7 , olistolith-olistostrome emplacement, large-scale sedimentary sliding; 8, strike-slip faulting.
By the end of the Paleocene, the northern edge of the foreland basin (the deepest part with flysch deposits) underwent the first folding; olistoliths and olistostromes incorporated in these structures may represent either large-scale sedimentary sliding or argilokinetic features (see Valery et al., 1985). The maximum deformation occurred by the end of the middle Eocene. On the southern edge of the foreland basin (Fig. 5), this episode was recorded as a shallowing period with a subsequent hiatus of the upper Eocene. Near the Eocene/Oligocene boundary a W-E compression produced (or reactivated) a rather complex fault system (Fig. 6) and the birth of molassic basins. During the early Miocene, extension and subsidence became stronger and a huge, dextral, W-E to WNW-ESE oriented, strike-slip fault system developed, similar to the faults bounding the Caribbean Plate (see Fig. 7). As stated earlier, a significant change occurred by the end of the Eocene and the beginning of the Oligocene: separation of the sedimentation from a northern marineoceanic influence appears related to the eastward displacement of the Caribbean Plate along the Bocono-El Pilar system (see Fig. 7); During this same period, at Site 672, the coarse terrigenous and calcareous inputs progressively disappeared. Thus we propose to relate these three facts: sedimentation on the Atlantic abyssal plain at Site 672, sedimentation on the northern South America shelf and slope, and structural evolution of the latter.

\section{DISCUSSION AND CONCLUSIONS}

Although we did not carry out the same detailed sediment analyses on northern Venezuela outcrops as on Site 672 cores, we attempt a comparison and point out the following facts:

1. On the southern edge of Venezuela foreland, glauconiterich sediments were widely developed during the middle Eocene and disappeared during the late Eocene-earliest Oligocene.

2. Sandy terrigenous lateral inputs at Site 672 are roughly coeval with flysch deposits on the northern edge of the foreland basin and with glauconite development on its southern edge.

3. At Site 672, deposition of glauconite-rich quartzose layers (continent-derived material) decreased near the Eocene/Oligocene boundary, precisely when huge east-west strike-slip faulting affected the central part of the foreland belt (area 1; Figs. 1 and 7) and stopped northern marine-oceanic influences in northern Venezuela Paleogene sedimentation. At Site 672, the input of silty-sandy material-which closely resembles the sedimentary content of northern Venezuela series-disappeared progressively when east-west dextral strike-slip faulting affected the latter area. We suggest that the arrival of the Caribbean Plate southeastern "corner" (see Figs. 7 and 8) on northern Venezuela progressively closed part of the terrigenous feeding of the Site 672 area. The minor amounts of very fine sand and silt found in the Oligocene section at Site 672 could be scattered middle-upper Eocene material reworked from further south on the Barbados Ridge slope.

The area located east of Trinidad may be considered a model for the Eocene stage of northern Venezuela foreland basin sedimentation (see Fig. 7):

1. Subsidence and flysch deposits on the north edge (the southern termination of the prism), with its submarine canyons and related turbidites;

2. Compressional tectonics with argilokinesis and reworking phenomena on the northwest edge; upper Miocene sediments were found reworked within Pleistocene series, close to the southeastern point of Trinidad, by Carr-Brown (1972);

3. Platform and upper slope sedimentation on the south edge. As in the model by Wright (1984), South-Atlantic bottom currents (b, c on Figs. 7 and 8 ) may be involved in transport of 
the sediments (clay and silt) derived from northern South America toward the north. Turbidites coming from deeper parts of the Orinoco cone and from the south termination of the Barbados complex, are reworked by roughly perpendicular bottom currents.

Bell (1968) and Beck (1986) reported different directions of dominant axial currents within the same series of interbedded contouritic horizons In the Eocene Guarico flysch (Fig. 8). Likewise, the arrival of coarse particles at Site 672 area involved long and complex reworking and may reflect the influence of turbidity and contour currents. We suggest that turbidity currents occurred on the South American continental slope, on the southern part of the accretionary complex (see Figs. 7 and 8), and on the slopes of Atlantic ocean bottom relief (see Dolan et al, this volume). Bottom (contour) currents may have been active on the Atlantic abyssal plain especially along the front of the accretionary complex. The location of these currents, particularly along the deformation front, progressively moved eastward as the prism grew. Several features may have caused local or general acceleration of these bottom currents; bottom relief of the oceanic plain (see the Tiburon Rise; and the lack of coarse terrigenous layers $20 \mathrm{~km}$ north of Site 672; Site 573, Shipboard Scientific Party, 1984), and the northward and northeastward increasing depth along the Lesser Antilles arc (from the Demerara Plain to the eastern termination of the Puerto Rico trench).

Despite the similarities, there are several differences between our Eocene reconstruction for Site $\mathbf{6 7 2}$ with the region east of Trinidad. In the latter (Fig. 7), the continental shelf is covered with the thick shaly Orinoco Delta, while the Eocene shelf of northern Venezuela (Fig. 8) was shallower and only slowly subsiding. During the early-middle Eocene, a situation equivalent to the east-of-Trinidad region may have existed in the present Maracaibo Lake region (Zambrano, et al., 1970; Stéphan, 1982).

In conclusion, we consider that the middle-upper Eocene sedimentation on the Atlantic Abyssal Plain at Site 672 is partly related to sedimentation and structural evolution of the central and western Venezuela margin. Using the present setting and our previous reconstructions for the Caribbean Chain (Beck, 1986), we propose a middle Eocene paleogeographic and paleostructural reconstruction for the southeastern corner of the Caribbean (Fig. 8). If the link between Site 672 (area 3) and northern Venezuela (areas 1 and 2 ) is real, then the proposed scheme is a constraint for the kinematics of the southeastern Caribbean and especially for the position of the Caribbean Plate.

\section{ACKNOWLEDGMENTS}

We are very grateful to Carol Pudsey and to Jean Dercourt for pertinent review and improvement of our manuscript.

\section{REFERENCES}

Barr, K. W., and Saunders, J. B., 1968. An outline of the geology of Trinidad. Trans. IVth Caribb. Geol. Conf., 1-10.

Beck, C., 1986. Géologie de la Chaîne Caraỉbe au méridien de Caracas. Soc. Géol. Nord, Lille, 14.

Bell, J. S., 1968. Geologia de la region de Camatagua, Estado Aragua, Venezuela. Boln. Geol. Minist. Minas, Caracas, 9:291-440.

Bell, J. S., 1972. Geotectonic evolution of the southern Caribbean area. In Shagam, R., et al. (Eds.), Studies in Earth and Space Sciences. Geol. Soc. Am. Mem. 132:369-386.

Bellizzia, A., 1972. Sistema montanoso del Caribe, borde sur de la Placa Caribe, es un cordillera alloctona? Trans. VIth Caribb. Geol. Conf., 247-258.

Blanc, G., Gieskes, J. M., Vrolijk, P., Mascle, A., Moore, J. C., Taylor, E., and Leg 110 Scientific Party, 1988. Advection des fluides interstitiels dans les séries sédimentaires du complexe d'accrétion de la Barbade (Leg 110 0.D.P.). Bull. Soc. Géol. France, 8:453-460.
Carr-Brown, B., 1972. The Holocene-Pleistocene contact in the offshore area east of Galea Point, Trinidad, West Indies. Trans. VIth Caribb. Geol. Conf., 381-397.

Chevalier, Y., 1987. Les zones internes de la Chaine Sud-Caraibe sur le transect ile de Margarita-péninsule d'Araya [Thèse]. Univ. de Brest.

Galea-Alvarez, F., 1985. Biostratigraphy and Depositional Environment of the Upper Cretaceous-Eocene Santa Anita Group (Northern Venezuela): Amsterdam (Free Univ. Press).

Gieskes, J. M., Blanc, G., Vrolijk, P., and Leg 110 Scientific Party, in press. Hydrogeochemistry in the Barbados accretionary complex: Leg 110 O.D.P. Tectonophysics.

Gonzalez de Juana, C., Iturralde de Arozena, J. M., Picart Cadillat, X., 1980. Geologia de Venezuela y de Sus Cuencas Petroliferas: Caracas (Ed. Foninves).

Hedberg, H. D., 1950. Geology of the Eastern Venezuela Basin- (Anzoategui, Sucre, Monagas, Eastern Guarico portion). Geol. Soc. Am. Bull., 61:1173-1216.

Higgins, G. E., and Saunders, J. B., 1974. Mud volcanoes: their nature and origin. Verhandl. Naturf. Ges., Basel, 84, 1:101-152.

Kügler, H. G., and Saunders, J. B., 1967. On Tertiary turbidity-flow sediments in Trinidad W. I. Assoc. Venez. Geol. Min. Petrol., 10: 243-259.

Latouche, C., and Maillet, N., 1984. Evolution of Cenozoic clay assemblages in the Barbados Ridge (Deep Sea Drilling Project Sites 541, 542, 543). In Biju-Duval, B., Moore, J. C., et al., Init. Repts. DSDP, 78A: Washington (U.S. Govt. Printing Office), 343-356.

Mascle, A., Cazes, M., Le Quellec, P., 1985. Structure des marges et bassins caraibes: une revue. In Mascle, A. (Ed.), Symp. Caribbean Geodynamics: Paris (Technip.), 1-20.

Mascle, A., Moore, J. C., and Leg 110 Scientific Party, 1988. Synthesis of shipboard results: Leg 110 transect of the northern Barebados Ridge. Proc. ODP, Init. Repts., 110: College Station, TX (Ocean Drilling Program), 577- 591.

Molnar, P., and Sykes, L. R., 1969. Tectonics of the Caribbean and Middle America regions from focal mechanisms and seismicity. Geol. Soc. Am. Bull., 80:1639-1686.

Moore, J. C., Mascle, A., Taylor, E., Alvarez, F., Andreieff, P., Barnes, R., Beck, C., Behrmann, J., Blanc, G., Brown, K., Clark, M., Dolan, J., Fisher, A., Gieskes, J., Hounslow, M., McClellan, P., Moran, K., Ogawa, Y., Sakai, T., Schoonmaker, J., Vrolijk, P. J., Wilkens, R., Williams, C., 1987. Expulsion of fluids from depth along a subduction-zone décollement horizon. Nature, 326:785-788.

Peirson, A. L., Salvador, A., Stainforth, R. M., 1966. The Guarico Formation of North-central Venezuela. Assoc. Venez. Geol. Min. Petrol., 9:183-224.

Pudsey, C., 1984. X-ray mineralogy of Miocene and older sediments from Deep Sea Drilling Project Leg 78A. In Biju-Duval, B., Moore, J. C., et al., Init. Repts. DSDP, 78A: Washington (U.S. Govt. Printing Office), 325-341.

Pudsey, C., and Reading, H. G., 1982. Sedimentology and structure of the Scotland Group, Barbados. In Legget, J. K. (Ed.), Trench Forearc Geology. Geol. Soc. London, Spec. Publ., 10:291-308.

Rossi, T., 1985. La Serrania del Interior Oriental (Vénézuela) sur le transect Cariaco-Maturin [Thèse]. Univ. de Brest.

Saunders, J. B., 1974. Trinidad. In Spencer, A. M. (Ed.), Mesozoic Cenozoic Orogenic Belts. Data for Orogenic Studies: Edinburgh (Scott. Acad. Press), 671-682.

Shipboard Scientific Party, 1970. Sites 26 and 27. In Bader, R. G., Gerard R. D., et al., Init. Repts. DSDP, 4: Washington (U.S. Govt. Printing Office), 77-123.

Shipboard Scientific Party, 1984. Site 543. Oceanic reference site east of the Barbados ridge complex. In Biju-Duval, B., and Moore, J. C., Init. Repts. DSDP, 78A: Washington (U.S. Govt. Printing Office), 227-252.

Shipboard Scientific Party, 1988. Site 672. In Mascle, A., Moore, J. C., et al., Proc. ODP, Init. Repts., 110: College Station, TX (Ocean Drilling Program), 205-250.

Speed, R. C., 1981. Geology of Barbados: implication for an accretionary origin. XXVIth Intern. Geol. Congr., Paris C-3; Oceanol. Acta, 4:259-265.

Speed, R. C. and Larue, D. K., 1982. Barbados: architecture and implication of accretion. J. Geophys. Res., 87:3633-3643.

Speed, R. C., Westbrook, G. K., et al., 1984. Lesser Antilles and adjacent terranes. Ocean Margin Drilling Program, Atlas 10. Regional Atlas Series, Woods Hole (Marine Sci. Inter.). 
Stéphan, J. F., 1982. Evolution géodynamique du domaine Caraïbe, Andes et Chaîne Caraỉbe sur la transversale de Barquisimeto (Vénézuela) [Thèse]. Univ. Pierre et Marie Curie, Paris.

1985. Andes et Chaîne Caraỉbe sur la Transversale de Barquisimeto (Vénézuela); évolution géodynamique. In Mascle, A. (Ed.), Symp. Caribbean Geodynamics, 505-530.

Stéphan, J. F., Beck, C., Bellizzia, A., Blanchet, R., 1980. La Chaîne Caraibe du Pacifique à l'Atlantique. XXVIth Intern. Geol. Congr., Paris C-5:38-59.

Stow, D.A.V., and Piper, D.J.W., 1984. Deep-water fine-grained sediments: facies and models. In Stow, D.A.V., and Piper, D.J.V. (Eds.), Fine-grained Sediments: Deep-water Processes and Facies. Geol. Soc. London, Spec. Publ., Oxford (Blackwell Sci. Publ.), 611-646.

Valéry, P., Nely, G., Mascle, A., Biju-Duval, B., Le Quellec, P., Berthon, J. L., 1985. Structure et croissance d'un prisme d'accrétion tectonique proche d'un continent: la Ride de la Barbade au Sud de l'arc antillais. In Mascle, A. (Ed.), Symp. Caribbean Geodynamics, 173-185.

Vierbuchen, R., 1978. Geology of the El Pilar fault region, State of Sucre, Venezuela, and its tectonic implications [Ph.D. Dissert.]. Princeton Univ.

Wright, A., 1984. Sediment distribution and depositional processes operating in the Lesser Antilles intra-oceanic island arc, eastern Caribbean. In Biju-Duval, B., Moore, J. C., et al., Init. Repts. DSDP, 78A: Washington (U.S. Govt. Printing Office), 301-324.

Zambrano, E., Vasquez, E., Duval, B., Latreille, M., Coffinièes, B., 1970. Synthèse paléogéographique et pétrolière du Vénézuela occidental. Rev. I. F. P., Paris, Vol. XXV: 12:1449-1491 (Technip).

Date of initial receipt: 22 September 1988

Date of acceptance: 2 March 1989

Ms 110B-120

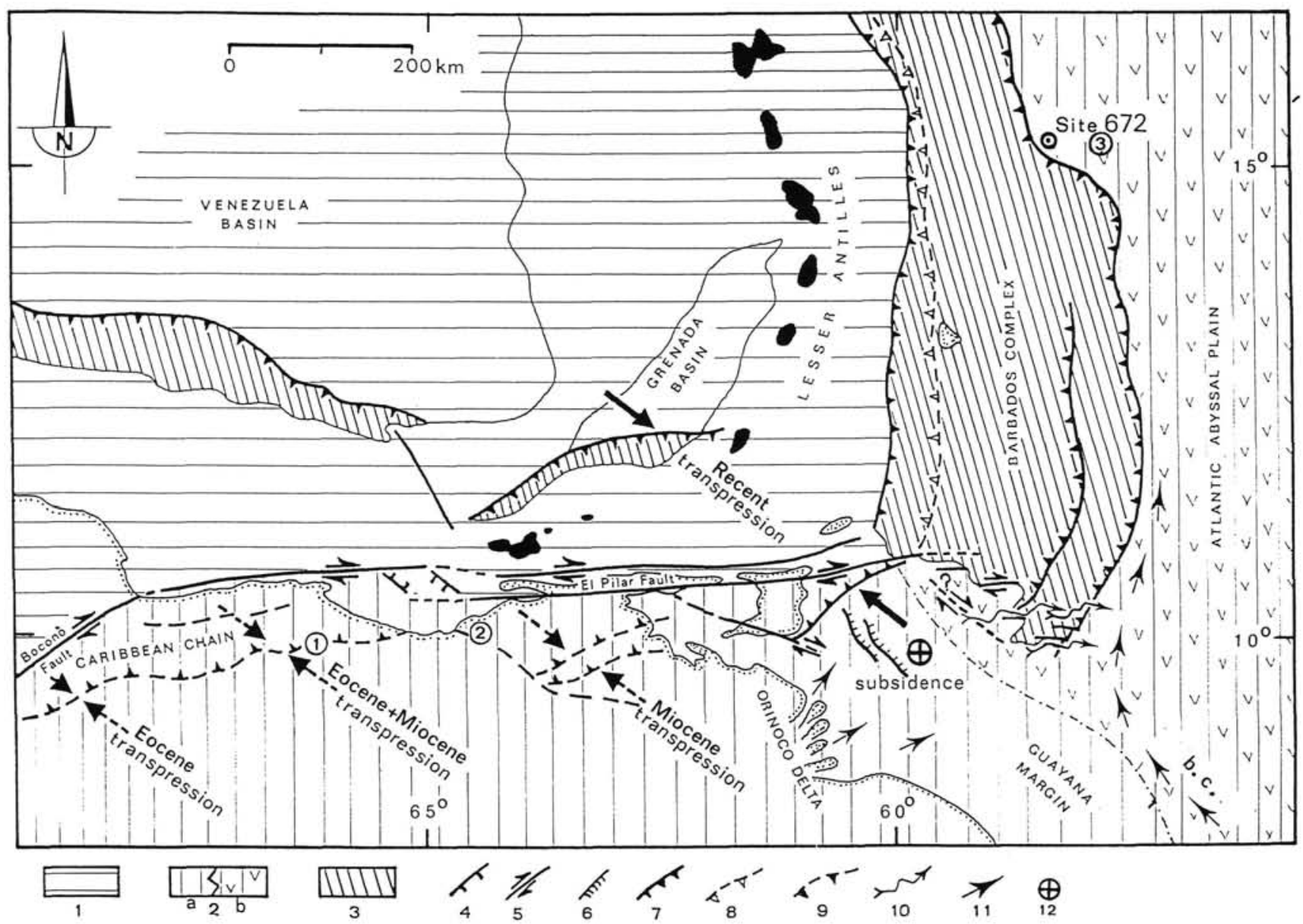

Figure 7. Principal active structures of the southeastern Caribbean. (Data from Stéphan, Mascle et al., 1985; Rossi, 1985; Beck et al., this volume). Legend: 1, Caribbean Plate; 2, South-America Plate; a, continental portion; b, oceanic portion; 3, Tertiary to Holocene accreted complexes; 4 , normal faulting; 5 , strike-slip faulting; 6 , gravity faulting within undercompacted thick sediments; 7 , thrusting; 8 , subduction trace; 9, Paleogene-Neogene thrusts; 10 , submarine canyons; 11 , main terrigenous feeding pathways to Barbados accretionary complex; 12 , area of maximum subsidence. 


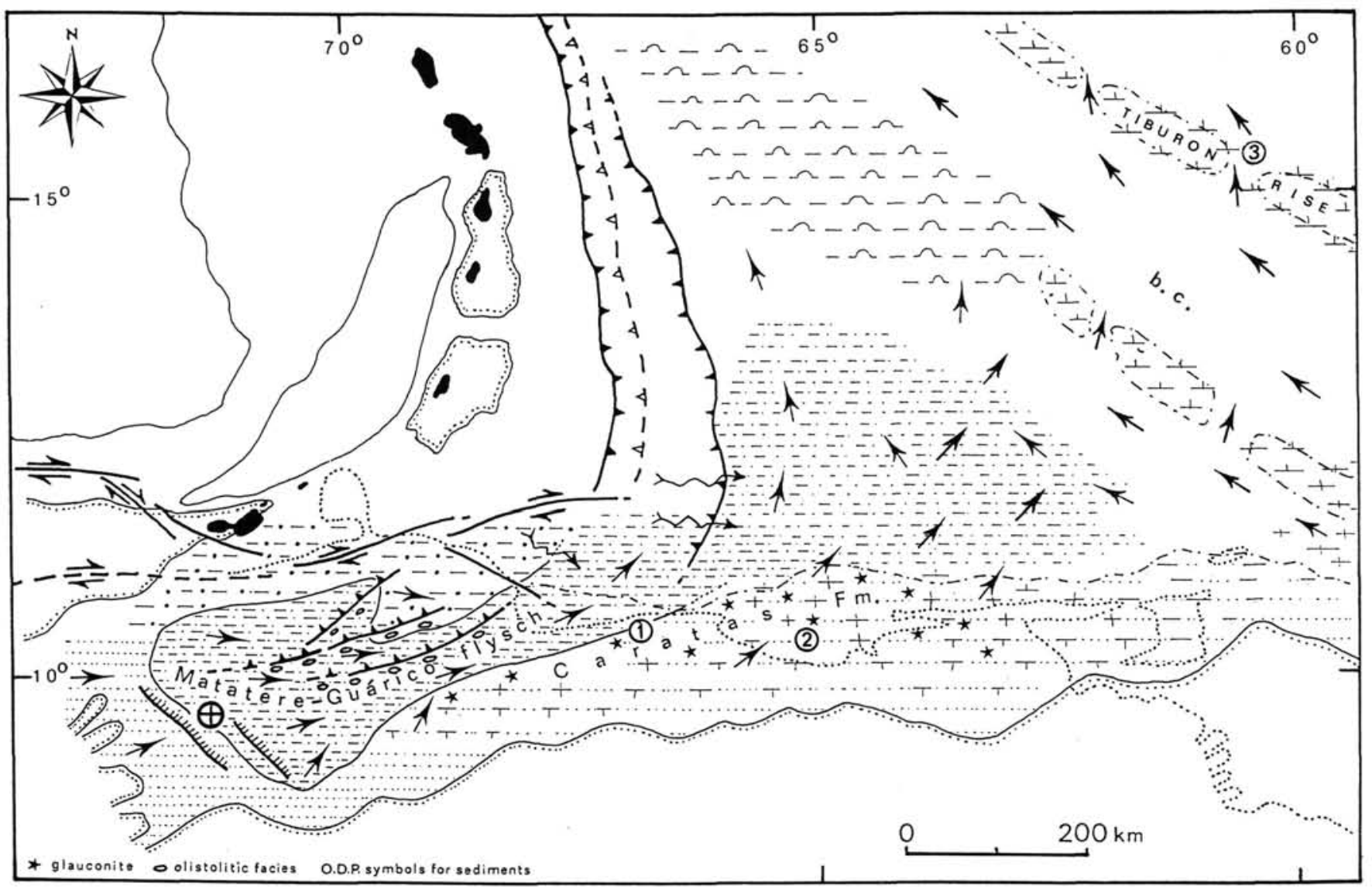

Figure 8. Proposed palinspastic reconstruction for the southeastern Caribbean during middle Eocene. (Same legend as for Fig. 7.) 